DOI: 10.22363/2313-0245-2021-25-3-229-234

RESEARCH ARTICLE

НАУЧНАЯ СТАТЬЯ

\title{
Cardiovascular risk factors in rural areas: case of the Mabayi health district hospital in Burundi
}

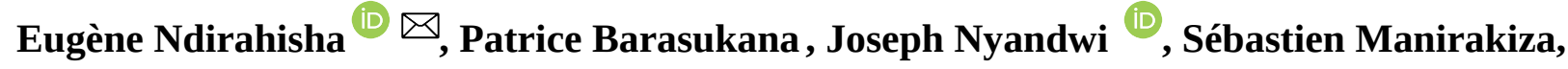 \\ Rhamadhan Nyandwi ${ }^{\mathbb{D}}$, Elysée Baransaka \\ University of Burundi, Faculty of Medicine, Bujumbura, Burundi \\ $\varangle$ kabandaeugene@yahoo.fr
}

\begin{abstract}
Relevance. Noncommunicable diseases are a serious public health problem due to their high incidence and mortality rate. Globally, noncommunicable diseases cause 41 million deaths every year, accounting for $71 \%$ of the total number of deaths. Cardiovascular diseases, accounting for $44 \%$ of all noncommunicable diseases, are the leading causes of death. Early identification of the main risk factors for cardiovascular diseases and treatment of associated diseases are a prerequisite for maintaining the health of the population. Objective: To identify the main risk factors for cardiovascular disease in patients living in rural areas of the mountainous region and attending the Mabayi District Hospital in Burundi. Patients and Methods. An open-label retrospective study conducted at the Mabayi District Hospital in Burundi from January 2014 to December 2017. The study included patients whose medical examination revealed at least one risk factor for cardiovascular diseases. The study was approved by the ethics committee of the Kamenge University Hospital and the Faculty of Medicine of the University of Burundi. Data analysis was carried out using Microsoft Word 2007 and Epi-Info TM 7.2.1.0 software. Results and Discussion. Among the 20297 examined patients, the average age was $50 \pm 16.7$ years, the extreme values were 14 and 101 years. Male patients accounted for 51.1\%. 903 patients (4.5\%) had at least one risk factor. The main risk factors were high blood pressure (52.6\%), diabetes (42.0\%) and alcohol abuse (27.4\%). Conclusion. Residents of rural areas of the mountainous region of Burundi have a high frequency of risk factors for cardiovascular diseases, which must be taken into account when organizing medical and preventive measures to prevent cardiovascular diseases.
\end{abstract}

Keywords: cardiovascular, prevalence, risk factor, rural areas, Burundi

Author contributions. All authors contribute to the writing of this manuscript. All authors read and approved the final manuscript.

Conflicts of interest statement. The authors declare no conflict of interest.

Received 04.02.2021. Accepted 11.03.2021.

(C) Ndirahisha E., Barasukana P., Nyandwi J., Manirakiza S., Nyandwi R., Baransaka E., 2021

This work is licensed under a Creative Commons Attribution 4.0 International License

https://creativecommons.org/licenses/by/4.0/ 
For citation: Ndirahisha E, Barasukana P, Nyandwi J, Manirakiza S, Nyandwi R, Baransaka E. Cardiovascular risk factors in rural areas: case of the Mabayi health district hospital in Burundi. RUDN Journal of Medicine. 2021;25(3):229—234. doi: 10.22363/2313-0245-2021-25-3-229-234

\section{Introduction}

Noncommunicable diseases are a serious public health problem due to their high incidence and mortality rate. Globally, noncommunicable diseases cause 41 million deaths every year, accounting for $71 \%$ of the total number of deaths. Cardiovascular diseases, accounting for $44 \%$ of all noncommunicable diseases, are the leading causes of death $[1,2]$. As the means of control is first of all preventive with an early diagnosis based on support this necessarily requires better knowledge of cardiovascular risk factors (CVRF). The prevalence of CVRF is variable worldwide [3]. This prevalence is continuously increasing and is becoming an important cause of morbidity and premature mortality [4]. It can be explained by the increase of the population, by the growing urbanization and the modes of production which tend towards the western model [3].

In Burundi, few studies have been carried out to assess the prevalence of CVRF. The objective of this work, carried out in a mountain population located in the west of Burundi at $80 \mathrm{~km}$ in the north of Bujumbura city, was to estimate the prevalence of the main CVRF in the area, as well as their distribution according to the gender and age.

\section{Patients and methods}

This is a descriptive retrospective study conducted at the Mabayi Health District Hospital from January 2014 to December 2017, a period of four years. Any patient seen in external consultation with at least one CVRF was included. Data collection was carried out using a pre-established survey form. Studied variables concerned socio-demographic characteristics, biometric measurements and biological. A clinical examination with blood pressure measurement and anthrometric measurements (weight, height, waist circumference) were carried out. Blood pressure was measured by an electronic blood pressure monitor three times at one minute intervals in subjects who had been resting for at least 5 minutes. Hypertension has been defined by systolic blood pressure greater than or equal to $140 \mathrm{~mm}$ $\mathrm{Hg}$ and/or diastolic pressure greater than or equal to 90 $\mathrm{mm} \mathrm{Hg}$. People under antihypertensive drugs are also considered hypertensive [5]. Abdominal obesity has been defined by a waist circumference greater than 102 $\mathrm{cm}$ in men and greater than $88 \mathrm{~cm}$ in women [6]. The body mass index (BMI), calculated according to the formula: $\mathrm{BMI}=$ weight in $\mathrm{Kg} /$ height2 in $\mathrm{cm}$, defined obesity by a BMI greater than or equal to $30 \mathrm{Kg} / \mathrm{m} 2$ [7]. Diabetes was considered before a fasting blood sugar level greater or equal to $1.26 \mathrm{~g} / \mathrm{l}$ [8]. Physical inactivity was defined by the absence of moderate physical exercise of at least 30 minutes daily which is equivalent to half an hour of brisk walking [9].

For ethical reasons, we have received authorization from the ethics committee of the Kamenge University Hospital and the Faculty of Medicine of the University of Burundi. Locally, we obtained authorization from the head of the Mabayi health district. Data entry and analysis was carried out using Microsoft word 2007 and Epi-Info TM 7.2.1.0 software.

\section{Results and Discussion}

Among 20,297 patients who visited Mabayi hospital, 903 had at least one CVRF, a prevalence of $4.5 \%$. Men with 461 cases $(51.1 \%)$ were the most numerous. Women accounted $48.9 \%$ of cases. The mean age was $50 \pm 16.7$ years with extremes ranging from 14 and 101 years. The most represented group was between 45 and 54 years old $21.7 \%$ of cases.

The married patients with 796 cases (88.2 \%) were the most numerous, followed in descending order by the unmarried (7.2\%), widowed (4.2\%) and by divorced $(0.4 \%)$. The cultivators were the most numerous with 693 cases $(76.7 \%)$. Unemployed were the least 
represented with $0.7 \%$ of cases. Civil servants (10.7\%), traders (5.9\%), pupils (4.7\%) and students (1.3\%) occupied the intermediate position.

Table 1

Distribution of patients by age groups

\begin{tabular}{|c|c|c|}
\hline Age groups & Number & Percentage, \% \\
$5-14$ & 1 & 0.1 \\
\hline $15-24$ & 99 & 11.0 \\
\hline $25-34$ & 139 & 15.4 \\
\hline $35-44$ & 139 & 15.4 \\
\hline $45-54$ & 196 & 21.7 \\
\hline $55-64$ & 187 & 20.7 \\
\hline 65 and more & 142 & 15.7 \\
\hline Total & 903 & 100.0 \\
\hline
\end{tabular}

Table 2

Distribution of patients by cardiovascular risk factors

\begin{tabular}{|c|c|c|}
\hline Risk factor & Number $(\mathrm{N}=903)$ & Percentage, \% \\
\hline High blood pressure & 475 & 52.6 \\
\hline Diabetes & 380 & 42.0 \\
\hline Alcohol abuse & 251 & 27.7 \\
\hline Obesity & 96 & 10.6 \\
\hline Tobacco & 94 & 10.4 \\
\hline Sedentarily & 29 & 3.2 \\
\hline Dyslipidemia & 4 & 0.4 \\
\hline
\end{tabular}

The modifiable CVRF were dominated by high blood pressure with $52.6 \%$ of cases. Among these hypertensive patients, 240 (50.5\%) were female. The average age was $53 \pm 15.2$ years with extremes of 15 and 101 years. The modal class was that of 45 to 54 years with $28.8 \%$ of cases. The cultivators represented the largest number of hypertensive patients with 389 cases or $81.9 \%$ of cases. Civil servants and traders followed respectively with 45 cases and 26 cases (9.5\% and $5.5 \%$ of cases). The prevalence of diabetes was $42.0 \%$ of all patients with at least one CVRF. The diabetes was associated with hypertension in 66 patients (7.3\%). By sex, $52.6 \%$ were male against 180 women (47.4\%). The most affected age group was the group of 55 to 64 years with 102 cases (26.9\%). Cultivators (74.2\%) were the most numerous, followed by schoolchildren and pupils with 33 patients (8.7 \%). The consumption rate increased with age and the peak was in the 45 to 54 age group. Male patients were more consuming alcohol with $60.6 \%$ against $39.4 \%$ of women.

Obese were 96 (10.6\%) of whom 46 (47.9\%) were farmers and 29 (30.2 \%) were traders. Female patients were the most numerous in obese with 52 cases (54.2\%). Ninety-four patients (10.4\%) regularly smoked tobacco. Seventy-two (74.5\%) were male against 24 women $(25.5 \%)$. The prevalence of sedentary people was $3.2 \%$. Sedentary women were more numerous with 19 cases (65.5\%). Dyslipidemia was observed in 4 patients $(0.4 \%)$. Women under oral contraceptives were $29.4 \%$.

The objective of our study was to identify the prevalence of the main CVRF in rural areas and its distribution by sex and age. According to the literature [10], CVRF are multiple and many patients combine several, which put them at high risk of developing CVD. In the WHO report, AFR/ RC55/12 [11], one of the reasons for the increase incidence of CVD worldwide is the number of elderly people. The other reason is exposure to behavioral and physiological risk factors which are responsible for $75 \%$ of all cardiovascular diseases. In our study, the prevalence of cardiovascular risk factors was $4.5 \%$ and the average age was $50 \pm 16.7$ years with extremes ranging from 14 and 101 years.

In our study, the prevalence of all CVRF increased with age. Indeed, we recorded a cases $(0.1 \%)$ for the group of 5 to 14 years against $196(21.7 \%)$ for that of 45 to 54 years. They were 142 (15.7\%) for patients aged 65 and over. In the city of Meknes (Morocco) in 2018, El Ghazi I and al. [12] found 4 (0.3 \%) before 14 years of age and $78.6 \%$ in patients aged 50 and over. According to the literature [13], age is by far the most important factor in the onset and worsening of cardiovascular disease, with approximately a threefold increase in risk for each decade of life.

Men are more exposed to risk factors compared to pre-menopausal women who join or exceed them after menopause [13]. In our study, men with 461 cases (51.1\%) were the most numerous against $48.9 \%$ of cases for women. This is explained by the fact that our patients are relatively young with a large proportion of 
women who are not yet menopausal. In our study, the modifiable CVRF were dominated by hypertension with $52.6 \%$ of cases. Among them, 240 (50.5\%) were female. The modal class was the 45 to 54 age group with $28.8 \%$ of cases. According to Fourcade L and al. [14], hypertension is the most common risk factor in terms of cardiovascular mortality and morbidity. In sub-Saharan Africa, it currently affects 27 to $28 \%$ of the population aged 20 and over; and its frequency increases with age [14]. The increase in the prevalence of diabetes, one of the main cardiovascular risk factor, is manifestly linked to the epidemic of obesity, poor diet and insufficient exercise [11]. In our study, the prevalence of diabetes was $42.0 \%$ of which $52.6 \%$ were male. Farmers $(74.2 \%)$ were the most numerous, followed by schoolchildren and pupils with $8.7 \%$ of cases. El Ghazi I and al. [12] found that the prevalence of diabetes was $23 \%$. According to the literature [12-15], age, gender, tobacco, high blood pressure, dyslipidemia and diabetes are very important indicators of future CVD in population that does not have disease. Their association increases the risk. In our study, hypertension, the most common of all modifiable risk factor, was associated with diabetes in 66 cases (7.3\%).

\section{Conclusion}

The rate of CVRF is high in rural areas in Burundi. Their distribution is of interest to women as well as men of all age. However, their frequency and cumulative increase with age. The most common, in descending order, were high blood pressure, diabetes, alcohol abuse, obesity and smoking at the same time, the dependence on gender and age is not significant. Thus, residents of rural areas of the mountainous region of Burundi have a high frequency of risk factors for cardiovascular diseases, which must be taken into account when organizing medical and preventive measures to prevent cardiovascular diseases.

\section{References}

1. World Health Organization. Noncommunicable diseases. Key facts. 2021. https://www.who.int/news-room/fact-sheets/detail/ noncommunicable-diseases. (Accessed January 10, 2021)

2. World Health Organization. The top 10 causes of death. WHO Media Centre: The top 10 causes of death. 2017. (Accessed January 10, 2021)

3. Boutayeb A et al. The double burden of communicable and non-communicable diseases in developing countries. Tropical Medicine and Hygiene. 2006;100:191-9.

4. Rguibi M and Belahcen R. Prevalence of obesity in Morocco. Obesity reviews. 2007;8:11-3.

5. Chobanian AV, Bakris GL, Black HR et al. The seventh report of the joint national committee on prevention, detection. Evaluation and treatment of high blood pressure. The JNC7 report. JAMA. 2003;289:2560-72.

6. Chiche F, Giral P et al. Prise en charge des patients dyslipidémiques. Annales d'endocrinologie. 2009;70:119—125.

7. Branca F, Nikogosian H, Lobstein T. The challenge of obesity in the WHO European Region and strategies for response. British medical journal. 2007;13:34-41.

8. Lucidarme N, Domingues- Muriel E. Report of the expert committee on the diagnosis and classification of diabetes mellitus. Diabetes Care. 2007;20:1183-97.

9. Bernstein MS, Morabia A, Sloutskis D. Definition and prevalence of sedentary in an urban population. Am J Public Health. 1999;89:862 - 867.

10. Rudaz A, Rima A, Humair JP. Scores de risqué cardiovasculaire: pourquoi, comment et quand les utiliser? Rev Med Suisse. 2010;6:1809_ 1815.

11. OMS/Comité régional de l'Afrique. Les maladies cardiovasculaires dans la région Africaine: Situation actuelle et perspectives. AFR/RC55/12;17 juin 2005.

12. Ghazi El, Berni I, Menouni A, Kestemont MP, Amane M, Jaafari ES. Profil épidémiologique des maladies cardiovasculaires dans la ville de Meknès (Maroc). Eur Sc journal. 2018;14 (33):49—55.

13. Finegold JA, Asaria P, Francis DP. Mortality from ischaemic heart disease by country, region, and age: statics from world Health Organization and United Nations. International Journal of Cardiology. 2012;168 (2): 934-945.

14. Fourcade L, Paule P, Mafart B. Hypertension artérielle en Afrique subsaharienne: Actualité et perspectives. Med trop. 2007;67: 559-567.

15. Prevention of Cardiovascular Disease: Guidelines for Assessment and Management of Cardiovascular Risk. WHO. 2007. ISBN978-92-4-154717-8. (Accessed January 10, 2021) 


\title{
Факторы риска сердечно-сосудистых заболеваний в сельской местности на примере районной больницы Мабэйи в Бурунди
}

\author{
Э. Ндирахиша ${ }^{\otimes}$, П. Барасукана, Дж. Ньяндви ${ }^{(\mathbb{D})}$, С. Маниракиза, \\ Р. Ньяндви ${ }^{(\mathbb{D})}$, Э. Барансака
}

Университет Бурунди, Медицинский факультет, Бужумбура, Бурунди

$\varangle$ E-mail: kabandaeugene@yahoo.fr

\begin{abstract}
Аннотация. Актуальность. Неинфекционные заболевания представляют собой серьезную проблему общественного здравоохранения из-за высокой частоты встречаемости и уровня смертности. Ежегодно в мире неинфекционные заболевания являются причиной смертности 41 миллиона человек, что составляет 71 \% от общего количества умерших. Сердечно-сосудистые заболевания, на которые приходится 44 \% от всех неинфекционных заболеваний, занимают первую строчку среди основных причин смертности. Своевременное выявление основных факторов риска сердечно-сосудистых заболеваний и терапия ассоциированных заболеваний являются необходимым условием сохранения здоровья населения. Цель: определить основные факторы риска сердечно-сосудистых заболеваний, встречающиеся у пациентов, проживающих в сельской местности горного района и посещающих районную больницу Мабэйи в Бурунди. Пациенты и методы. Открытое ретроспективное исследование проведено в районной больнице Мабэйи в Бурунди с января 2014 года по декабрь 2017 года. В исследование были включены пациенты, в результате медицинского обследования которых обнаружен по крайней мере один фактор риска сердечно-сосудистых заболеваний. Исследование было одобрено этическим комитетом университетской больницы Каменге и медицинского факультета университета Бурунди. Анализ данных проводился с использованием программного обеспечения Microsoft Word 2007 и Epi-Info TM 7.2.1.0. Результаты и обсуждение. Среди 20297 обследованных пациентов средний возраст составлял $50 \pm$ 16,7 года, крайние значения - 14 и 101 год. Пациенты мужского пола составляли 51,1 \%. По крайней мере, один фактор риска имели 903 пациента (4,5 \%). Основными факторами риска были высокое артериальное давление (52,6 \%), диабет (42,0 \%) и злоупотребление алкоголем (27,4 \%). Выводы. У жителей сельской местности горного района Бурунди обнаружена высокая частота факторов риска сердечно-сосудистых заболеваний, что необходимо учитывать при организации лечебных и профилактических мероприятий по предупреждению сердечно-сосудистых заболеваний.
\end{abstract}

Ключевые слова: сердечно-сосудистая система, распространенность, фактор риска, сельские районы, Бурунди

Вклад авторов: авторы внесли равный вклад в подготовке рукописи.

Информация о конфликте интересов. Авторы декларируют отсутствие конфликта интересов.

Поступила 04.02.2021. Принята 11.03.2021.

Для цитирования: Ndirahisha E., Barasukana P., Nyandwi J., Manirakiza S., Nyandwi R., Baransaka E. Cardiovascular risk factors in rural areas: case of the Mabayi health district hospital in Burundi // Вестник Российского университета дружбы народов. Серия: Медицина. 2021. Т. 25. № 3. С. 229-234. doi: 10.22363/2313-0245-2021-25-3-229-234 
Corresponding author: Eugene Ndirahisha, MD, Teacher researcher of Cardiovascular disease, University of Burundi, Faculty of Medicine, Department of Internal Medicine, 1550, Bujumbura, Burundi. E-mail: kabandaeugene@yahoo.fr

Ndirahisha E. ORCID 000-0003-3243-1967

Nyandwi J. ORCID 0000-0002-3715-7891

Nyandwi R. ORCID 0000-0003-4371-425X

Baransaka E. ORCID 0000-0002-7796-6626

Ответственный за переписку: Эджин Ндирахиша, доктор медицины, преподаватель-исследователь сердечно-сосудистых заболеваний Университета Бурунди. Бурунди, 1550, г. Бужумбура, Университет Бурунди, Медицинский факультет. E-mail: kabandaeugene@yahoo.fr

Ндирахиша Э. ORCID 000-0003-3243-1967

Ньяндви Дж. ORCID 0000-0002-3715-7891

Ньяндви P. ORCID 0000-0003-4371-425X

Барансака Э. ORCID 0000-0002-7796-6626 